\title{
Attachment Style, Emotional Maturity and Self-Esteem among Adults with and Without Substance Abuse
}

\author{
Anjali Gupta ${ }^{1}$, Roopali Sharma ${ }^{2}$
}

\section{ABSTRACT}

The present study focuses on determining the difference between adults with and without substance abuse in their attachment style, emotional maturity and self-esteem and also whether there is gender difference in them. For the study, sample comprised of 80 participants, i.e. 40 substance abusers and 40 substance non abusers in which 20 males and 20 females of $18-30$ years from both the group were taken as sample. The primary reason of the study was that substance abuse is a persistent problem that many people suffer from and it is inexorably a growing issue that leads to social and economic influences. The results showed that there was significant difference among adults who abuse substances and who did not abuse substances. Participants who did not abuse substances showed secure attachment pattern, high emotional stability and high self-esteem as compared to participants who abuse substances. Also there was a significant gender difference in secure attachment pattern in non-abusers and in insecure attachment pattern in substance abusers. Females in comparison to males were more emotional stable in both the groups. No significant difference was seen in the self-esteem of males and females. The study provides an opportunity for further research across age and sub-divisions of the variables to uncover the possible differences or similarities that may be present.

Keywords: Attachment Style, Emotional Maturity, Self-Esteem, Adults, Substance Abuse

Substance abuse, also known as drug abuse, is a patterned use of a drug in which the user consumes the substance in amounts or with methods which are harmful to themselves or others, and is a form of substance-related disorder. Widely differing definitions of drug abuse are used in public health, medical and criminal justice contexts. The exact cause of substance abuse is not clear, with theories including: a genetic disposition; learned from others - or a habit which if addiction develops, manifests as a chronic debilitating disease. Drugs most often associated with this term include: alcohol, substituted amphetamines, barbiturates, benzodiazepines, cocaine,

\footnotetext{
${ }^{1}$ Student, Amity Institute of Psychology and Allied Sciences, Amity University, Noida, Uttar Pradesh, India

${ }^{2}$ Supervisor, Associate Professor, Amity Institute of Psychology and Allied Sciences, Amity University, Noida, Uttar Pradesh, India

*Responding Author

(c) 2016 I A Gupta, R Sharma; licensee IJIP. This is an Open Access Research distributed under the terms of the Creative Commons Attribution License (http://creativecommons.org/licenses/by/2.0), which permits unrestricted use, distribution, and reproduction in any Medium, provided the original work is properly cited.
} 


\section{Attachment Style, Emotional Maturity and Self-Esteem among Adults With and Without Substance Abuse}

methaqualone, and opioids. An estimated 7.5 crore Indians are drug addicts and the number is going up significantly, spreading to semi-urban and backward areas.

Attachment is a deep and enduring emotional bond that connects one person to another across time and space (Ainsworth, 1973; Bowlby, 1969). Four styles of attachment have been identified in adults: secure, anxious-preoccupied, dismissive-avoidant and fearful-avoidant. Securely attached adults tend to have positive views of themselves, their partners and their relationships. Anxious, dismissive and fearful attachment style together is considered as insecure attachment style. Adults with insecure attachment desire a high level of independence, often appearing to avoid attachment altogether or have mixed feelings about close relationships, both desiring and feeling uncomfortable with emotional closeness. Emotional maturity refers to your ability to understand, and manage, your emotions. Emotional maturity enables you to create the life you desire. Each person has a different level of emotional maturity. It is something which you can consistently work on and improve over time. Self-esteem is used to describe a person's overall sense of self-worth or personal value which involves a variety of beliefs about the self, such as the appraisal of one's own appearance, beliefs, emotions, and behaviors.

Substance abuse effects an individual physically, socially and even psychologically. Out of all the psychological factors that get affect by substance abuse, attachment pattern and self-esteem, emotional maturity has been chosen to be tested in the present study.

It is very important to have a healthy way of life to improve psychological wellbeing. Some psychological benefits include decreased mental illness, better ability to handle problems, increased self-esteem and cognitive abilities.

\section{REVIEW OF LITERATURE}

Rose et al. (2014) indicated that addiction or substance abuse can stunt emotional growth. They showed that adolescents who abuse alcohol or drugs have enormous difficulties transitioning into adulthood. Those who drink large volumes of alcohol or abuse drugs early in life will generally experience problems with emotional maturity.

Hatch (2013) said that addicts tend to be more emotionally immature than non-addicts. They are easily flooded with emotion to the point of impairing functioning. They tend to respond to frustrating situations as disasters rather than having any perspective. Addicts are often selfcentred and not good at dealing with the everyday requirements of life like being on time, fulfilling obligations and telling the truth.

Rajkumar (2012) investigated the emotional maturity and gender differences in government employees. The results of the study indicated that the female employees were found significantly better than the male employees in the area of emotional maturity skills and there is a significant 


\section{Attachment Style, Emotional Maturity and Self-Esteem among Adults With and Without Substance Abuse}

gender difference in emotional maturity. It was also noticed that employees in the government sector are emotionally unstable.

Winograd (2012) conducted a study that examined emotional maturity and alcohol use and found that when participants were interviewed at 25 years of age, some showed signs of alcohol use problems, but did not report any feelings of immaturity or lack of emotional development. However, when the same participants were interviewed later at the age of 29 and then again at the age of 35, there were individuals who showed signs of alcohol abuse and/or dependence as well as self-reported feelings of immaturity for their age.

Alavi (2011) studied the role of self-esteem in tendency towards drugs, theft and prostitution. It was found that self-esteem had a meaningful role in the individual's tendency to addiction, theft and prostitution. Hence, it was concluded that those who are involved in addiction, theft and prostitution have a lower self-esteem compared with the ordinary person.

Kararrmak\& Duran (2008) examined gender differences in attachment styles and explored the relationship between attachment styles and preference for conflict handling behavior in close relationships among Turkish adolescents. Results revealed an association between attachment styles and conflict handling, as well as gender differences in attachment styles.

Kassel, Wardle and Roberts (2007) plugs to a relationship between insecure attachment and drug use, particularly alcohol consumption. Simultaneous regression analyses revealed that, for drug use frequency, the influence of anxious attachment operated primarily through its effect on dysfunctional attitudes and self-esteem. Regarding drug use attributable to negative affect reduction, anxious attachment demonstrated direct, independent effects on both cigarette smoking and alcohol use. These findings highlight the potential importance of adult attachment styles as a risk factor for drug use among college students.

McNally et al. (2003) has found a positive association between insecure adult attachment styles and harmful drinking patterns. The results indicated that a negative model of self would contribute significantly to the variance in drinking problems over and above that accounted for by level of alcohol consumption.

Shrier et al. (2001) revealed that self-esteem is related inversely to tobacco use, alcohol use, and use of other drugs. Regardless of type of drug, recent users had the lowest self-esteem and never users had the highest scores. Race and gender were not associated significantly with self-esteem.

Kahn and Fawcett (1993) reported that lack of self-esteem can be correlated with increase in likelihood of some crimes and drug abuse. 


\section{METHODOLOGY}

Aim

- To study attachment style, emotional maturity and self-esteem among adults with and without substance abuse.

\section{Objectives}

- To identify the attachment styles among the adults with substance abuse and without substance abuse.

- To assess the level of emotional maturity among the adults with substance abuse and without substance abuse.

- To assess the level of self-esteem among the adults with substance abuse and without substance abuse.

- To compare male and female adults with and without substance abuse in relation to attachment style.

- To compare male and female adults with and without substance abuse in relation to emotional maturity.

- To compare male and female adults with and without substance abuse in relation to selfesteem.

\section{Hypothesis}

- There will be a significant difference in attachment style of adults with and without substance abuse.

- There will be a significant difference in level emotional maturity of adults with and without substance abuse.

- There will be a significant difference in self-esteem of adults with and without substance abuse.

- There will be a significant gender differences in attachment style of adults with and without substance abuse.

- There will be a significant gender differences in the level of emotional maturity of adults with and without substance abuse.

- There will be a significant gender differences in self-esteem of adults with and without substance abuse.

\section{Participants}

The sample comprised of 80 participants, i.e. 40 substance abusers and 40 substance non abusers in which 20 males and 20 females ranging between the age group of 18 - 30 years from both the group were taken as sample.

\section{Research Design:}

A comparative study on the lines of ex post facto research design is used. 


\section{Instrumentation:}

The tools which were used for the study included: Emotional Maturity Scale by Singh \& Bhargava (1990), Relationship Scale Questionnaire by Griffin \& Bartholomew (1994) and Rosenberg Self-Esteem Scale by Rosenberg (1965)

\section{Procedure:}

After collection of data of both adults with substance abuse and without substance abuse their scores were calculated and the raw data was inserted to a master chart. Statistical techniques that were used included mean scores and $t$ test. The hypothesis formulated were then accepted or rejected through the analysis of the scores.

\section{RESULTS}

Table 1 - Showing the mean, standard deviation, $t$ value obtained and significance of difference of Secure and Insecure Attachment between adults with substance abuse and without substance abuse.

\begin{tabular}{|c|c|c|c|c|c|c|}
\hline & & $\mathbf{N}$ & Mean & $\begin{array}{l}\text { Standard } \\
\text { Deviation }\end{array}$ & $t$ & $P$ \\
\hline \multirow{2}{*}{$\begin{array}{l}\text { Secure } \\
\text { Attachment }\end{array}$} & $\begin{array}{l}\text { Adults with } \\
\text { Substance Abuse }\end{array}$ & 40 & 1.76 & 0.46 & \multirow{2}{*}{21.750} & \multirow{2}{*}{$\mathrm{Sig}^{* * *}$} \\
\hline & $\begin{array}{l}\text { Adults without } \\
\text { Substance Abuse }\end{array}$ & 40 & 3.98 & 0.45 & & \\
\hline \multirow{2}{*}{$\begin{array}{l}\text { Insecure } \\
\text { Attachment }\end{array}$} & $\begin{array}{l}\text { Adults with } \\
\text { Substance Abuse }\end{array}$ & 40 & 4.17 & 0.36 & \multirow{2}{*}{22.647} & \multirow{2}{*}{$\operatorname{Sig}^{* * *}$} \\
\hline & $\begin{array}{l}\text { Adults without } \\
\text { Substance Abuse }\end{array}$ & 40 & 2.20 & 0.42 & & \\
\hline
\end{tabular}

$0.05^{*}, 0.01$

Table 2 - Showing the mean, standard deviation, $t$ value obtained and significance of difference of secure and insecure attachment between adult males and females with substance abuse.

\begin{tabular}{|c|c|c|c|c|c|c|}
\hline $\begin{array}{l}\text { Adults with } \\
\text { Abuse }\end{array}$ & Substance & $\mathbf{N}$ & Mean & $\begin{array}{l}\text { Standard } \\
\text { Deviation }\end{array}$ & $t$ & $P$ \\
\hline \multirow{2}{*}{$\begin{array}{l}\text { Secure } \\
\text { Attachment }\end{array}$} & $\begin{array}{l}\text { Male } \\
\text { Adults }\end{array}$ & 20 & 1.64 & 0.45 & \multirow{2}{*}{1.600} & \multirow{2}{*}{ In-sig } \\
\hline & $\begin{array}{l}\text { Female } \\
\text { Adults }\end{array}$ & 20 & 1.87 & 0.46 & & \\
\hline \multirow{2}{*}{$\begin{array}{l}\text { Insecure } \\
\text { Attachment }\end{array}$} & $\begin{array}{l}\text { Male } \\
\text { Adults }\end{array}$ & 20 & 4.33 & 0.33 & \multirow{2}{*}{3.013} & \multirow{2}{*}{$\operatorname{Sig}^{* * *}$} \\
\hline & $\begin{array}{l}\text { Female } \\
\text { Adults }\end{array}$ & 20 & 4.02 & 0.32 & & \\
\hline
\end{tabular}

$0.05^{*}, 0.01$ 
Table 3 - Showing the mean, standard deviation, $t$ value obtained and significance of difference of Secure and Insecure Attachment between adult males and females without substance abuse.

\begin{tabular}{|c|c|c|c|c|c|c|}
\hline \multicolumn{2}{|c|}{$\begin{array}{l}\text { Adults without } \\
\text { Substance Abuse }\end{array}$} & $\mathbf{N}$ & Mean & $\begin{array}{l}\text { Standard } \\
\text { Deviation }\end{array}$ & $T$ & $\boldsymbol{P}$ \\
\hline \multirow{2}{*}{$\begin{array}{l}\text { Secure } \\
\text { Attachment }\end{array}$} & $\begin{array}{l}\text { Male } \\
\text { Adults }\end{array}$ & 20 & 3.75 & 0.43 & \multirow{2}{*}{3.781} & \multirow{2}{*}{$\mathrm{Sig}^{* * *}$} \\
\hline & $\begin{array}{l}\text { Female } \\
\text { Adults }\end{array}$ & 20 & 4.21 & 0.34 & & \\
\hline \multirow{2}{*}{$\begin{array}{l}\text { Insecure } \\
\text { Attachment }\end{array}$} & $\begin{array}{l}\text { Male } \\
\text { Adults }\end{array}$ & 20 & 2.24 & 0.53 & \multirow{2}{*}{0.636} & \multirow{2}{*}{ In-sig } \\
\hline & $\begin{array}{l}\text { Female } \\
\text { Adults }\end{array}$ & 20 & 2.16 & 0.28 & & \\
\hline
\end{tabular}

$0.05^{*}, 0.01$

Table 4 - Showing the mean, standard deviation, $t$ value obtained and significance of difference of level of Emotional Maturity between adults with substance abuse and without substance abuse.

\begin{tabular}{|l|l|l|l|l|l|}
\hline & N & Mean & $\begin{array}{l}\text { Standard } \\
\text { Deviation }\end{array}$ & $\boldsymbol{T}$ & $\boldsymbol{P}$ \\
\hline $\begin{array}{l}\text { Adults with } \\
\text { Substance Abuse }\end{array}$ & 40 & 158.60 & 44.25 & 11.720 & $\mathrm{Sig}^{* * *}$ \\
\hline $\begin{array}{l}\text { Adults without } \\
\text { Substance Abuse }\end{array}$ & 40 & 74.55 & 9.94 & \\
\hline
\end{tabular}

$0.05^{*}, 0.01^{* *}$

Table 5 - Showing the mean, standard deviation, $t$ value obtained and significance of difference of Emotional Maturity between adult males and females with substance abuse.

\begin{tabular}{|l|l|l|l|l|l|}
\hline $\begin{array}{l}\text { Adults with } \\
\text { Substance } \\
\text { Abuse }\end{array}$ & $\mathbf{N}$ & Mean & $\begin{array}{l}\text { Standard } \\
\text { Deviation }\end{array}$ & $\boldsymbol{t}$ & $\boldsymbol{P}$ \\
\hline Male Adults & 20 & 188.20 & 32.19 & 5.670 & $\mathrm{Sig}^{* * *}$ \\
\hline Female Adults & 20 & 129.00 & 33.73 & & \\
\hline
\end{tabular}

$0.05^{*}, 0.01^{* *}$ 
Table 6 - Showing the mean, standard deviation, $t$ value obtained and significance of difference of Emotional Maturity between adult males and females without substance abuse.

\begin{tabular}{|l|l|l|l|l|l|}
\hline $\begin{array}{l}\text { Adults without } \\
\text { Substance } \\
\text { Abuse }\end{array}$ & $\mathbf{N}$ & Mean & $\begin{array}{l}\text { Standard } \\
\text { Deviation }\end{array}$ & $\boldsymbol{t}$ & $\boldsymbol{P}$ \\
\hline Male Adults & 20 & 78.40 & 8.08 & 2.627 & Sig $^{*}$ \\
\hline Female Adults & 20 & 70.70 & 10.32 & & \\
\hline
\end{tabular}

$0.05^{*}, 0.01$

Table 7 - Showing the mean, standard deviation, $t$ value obtained and significance of difference of Self-Esteem between adults with substance abuse and without substance abuse.

\begin{tabular}{|l|l|l|l|l|l|}
\hline & $\mathbf{N}$ & Mean & $\begin{array}{l}\text { Standard } \\
\text { Deviation }\end{array}$ & $\boldsymbol{t}$ & $\mathbf{P}$ \\
\hline $\begin{array}{l}\text { Adults with } \\
\text { Substance Abuse }\end{array}$ & 40 & 14.35 & 3.73 & 16.483 & Sig $^{* * *}$ \\
\hline $\begin{array}{l}\text { Adults without } \\
\text { Substance Abuse }\end{array}$ & 40 & 26.10 & 2.52 & \\
\hline
\end{tabular}

$0.05^{*}, 0.01^{* *}$

Table 8 - Showing the mean, standard deviation, $t$ value obtained and significance of difference of Self-Esteem between adult males and females with substance abuse.

\begin{tabular}{|l|l|l|l|l|l|}
\hline $\begin{array}{l}\text { Adults with } \\
\text { Substance Abuse }\end{array}$ & $\mathbf{N}$ & Mean & $\begin{array}{l}\text { Standard } \\
\text { Deviation }\end{array}$ & $\boldsymbol{t}$ & $\mathbf{P}$ \\
\hline Male Adults & 20 & 14.95 & 3.66 & 1.015 & In-sig \\
\hline Female Adults & 20 & 13.75 & 3.80 & \\
\hline
\end{tabular}


Attachment Style, Emotional Maturity and Self-Esteem among Adults With and Without Substance Abuse

Table 9 - Showing the mean, standard deviation, $t$ value obtained and significance of difference of Self-Esteem between adult males and females without substance abuse.

\begin{tabular}{|l|l|l|l|l|l|}
\hline $\begin{array}{l}\text { Adults without } \\
\text { Substance Abuse }\end{array}$ & $\mathbf{N}$ & Mean & $\begin{array}{l}\text { Standard } \\
\text { Deviation }\end{array}$ & $\boldsymbol{t}$ & $\boldsymbol{P}$ \\
\hline Male Adults & 20 & 26.20 & 2.58 & 0.248 & In- sig \\
\hline Female Adults & 20 & 26.00 & 2.51 & 0.248 & In-sig \\
\hline
\end{tabular}

Graph 1 - Showing the mean value of Secure Attachment and Insecure Attachment among adults with substance abuse and without substance abuse.

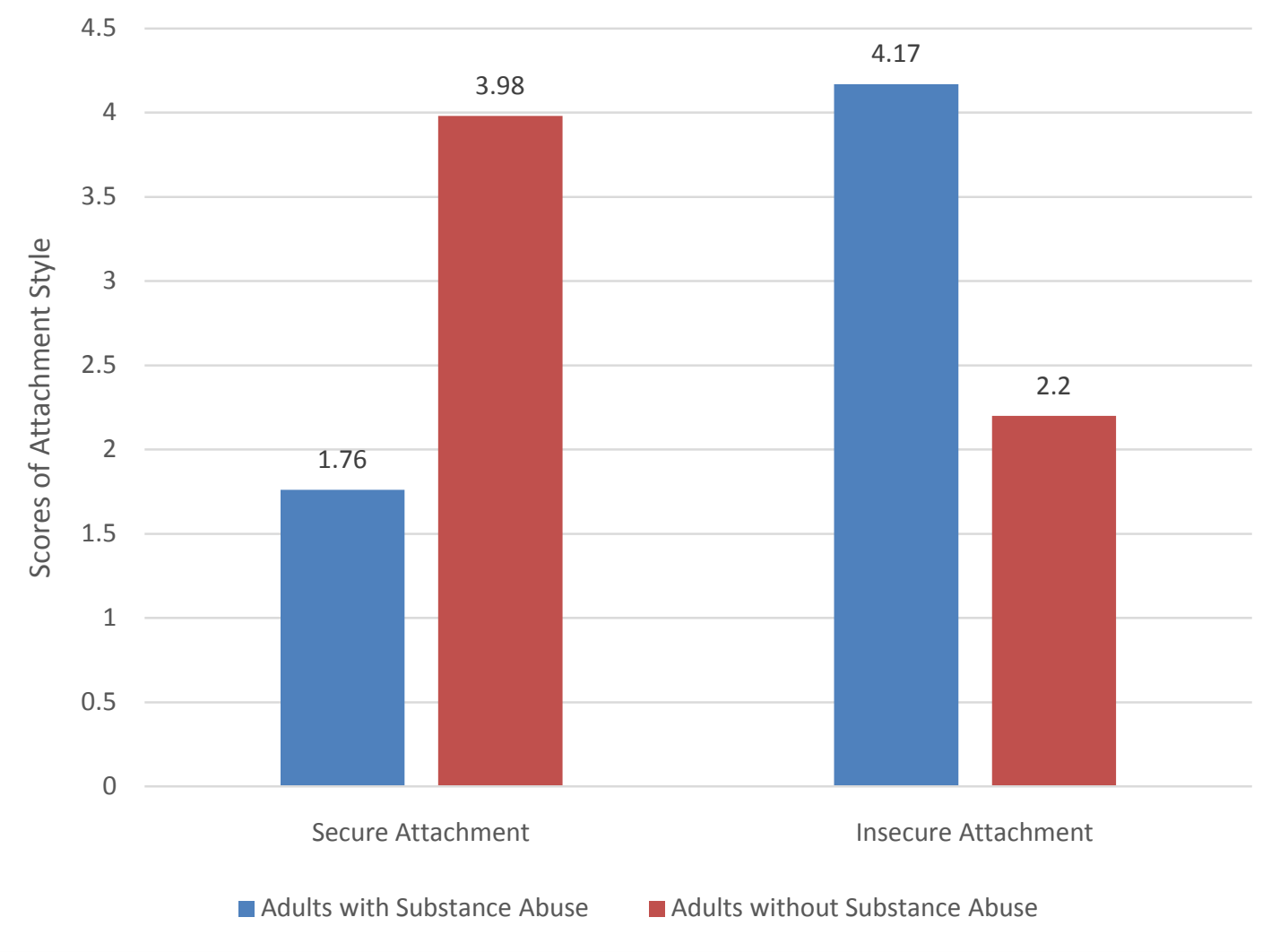


Attachment Style, Emotional Maturity and Self-Esteem among Adults With and Without Substance Abuse

Graph 2 - Showing the mean value of Secure and Insecure Attachment Style between adult males and females with substance abuse.

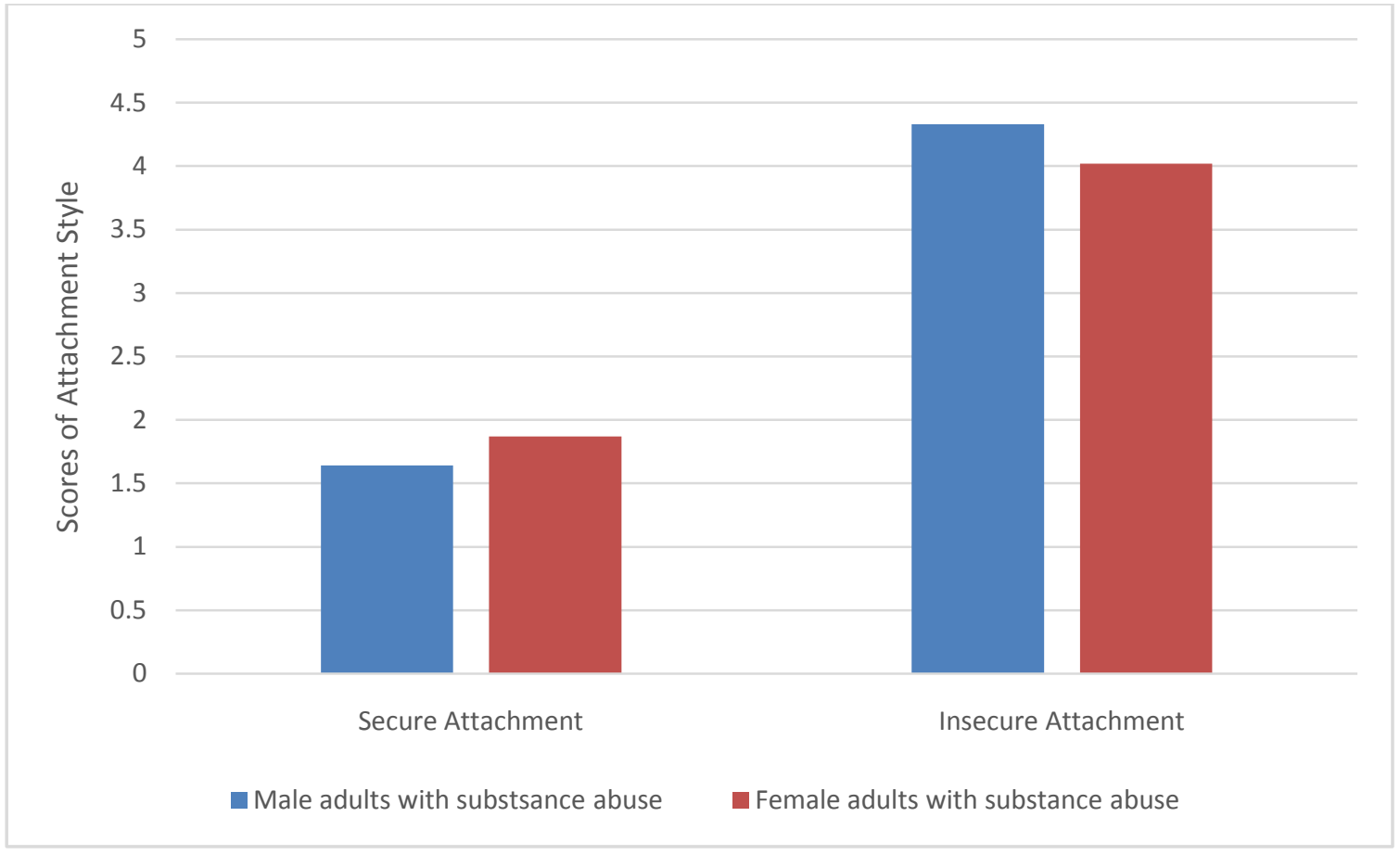

Graph 3 - Showing the mean value of Secure and Insecure Attachment Style between adult males and females without substance abuse.

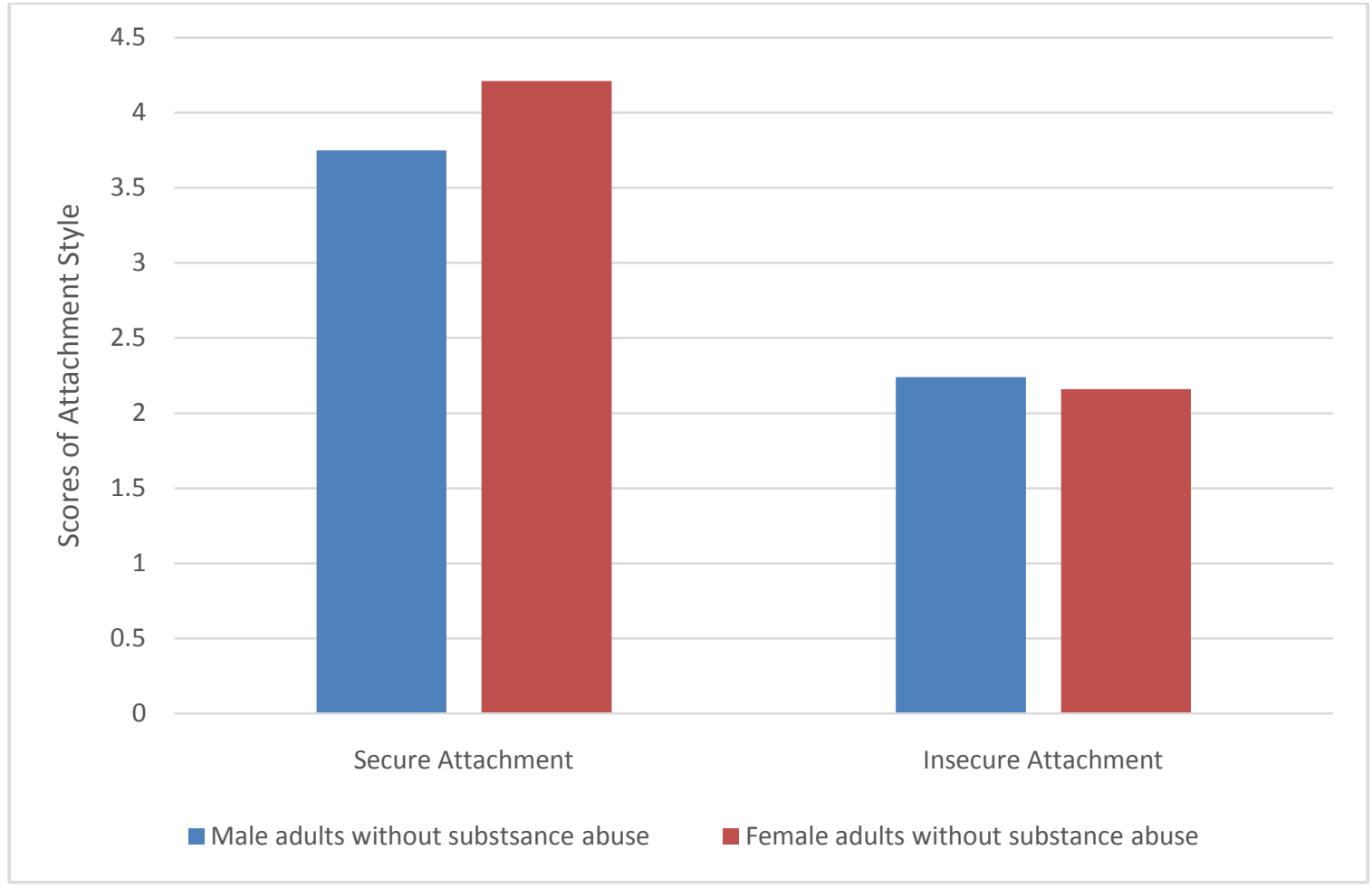


Attachment Style, Emotional Maturity and Self-Esteem among Adults With and Without Substance Abuse

Graph 4 - Showing mean value of Emotional Maturity among adults with substance abuse and without substance abuse.

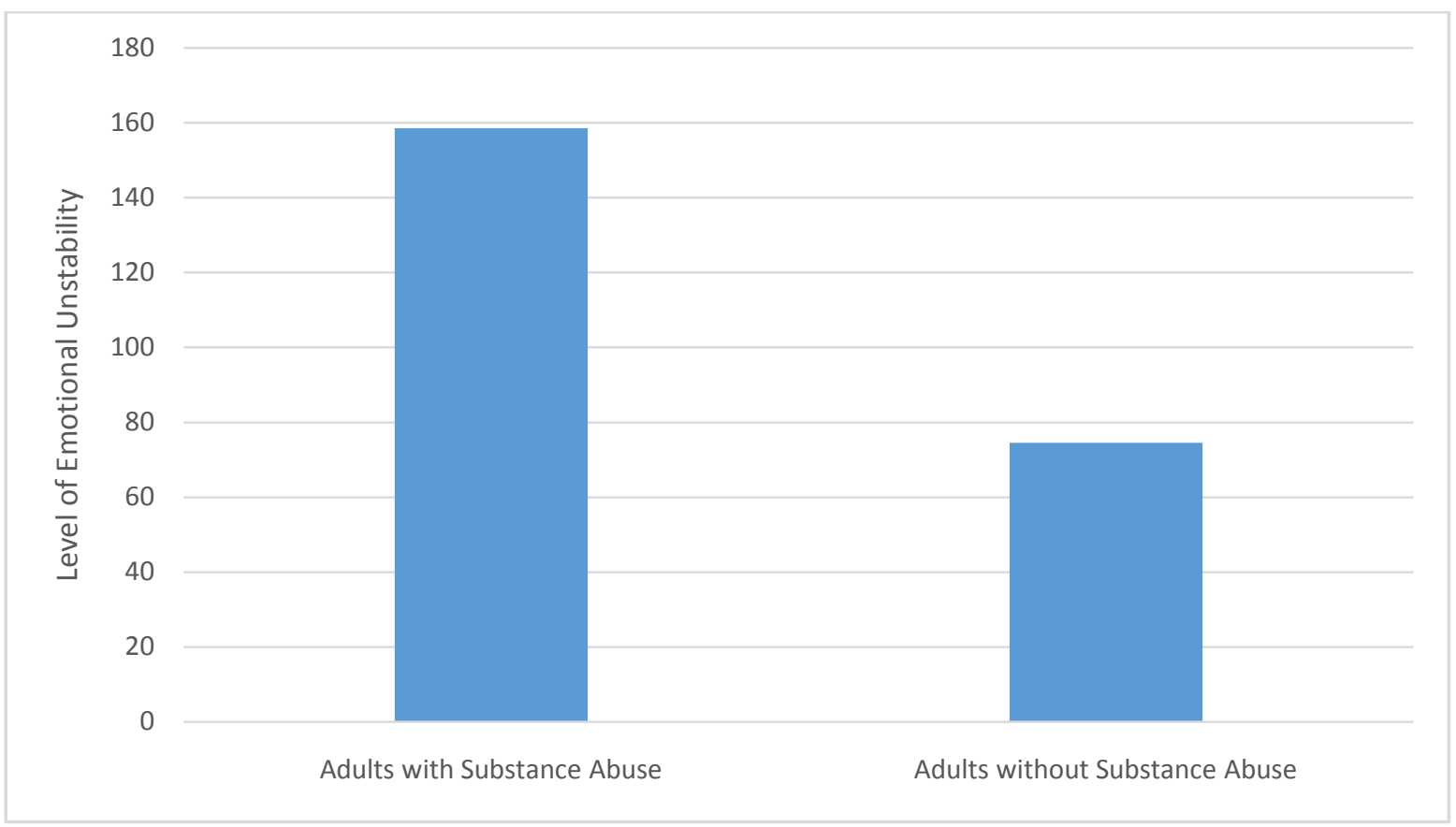

Graph 5 - Showing the mean value of Emotional Maturity between adult males and females with substance abuse and without substance abuse.

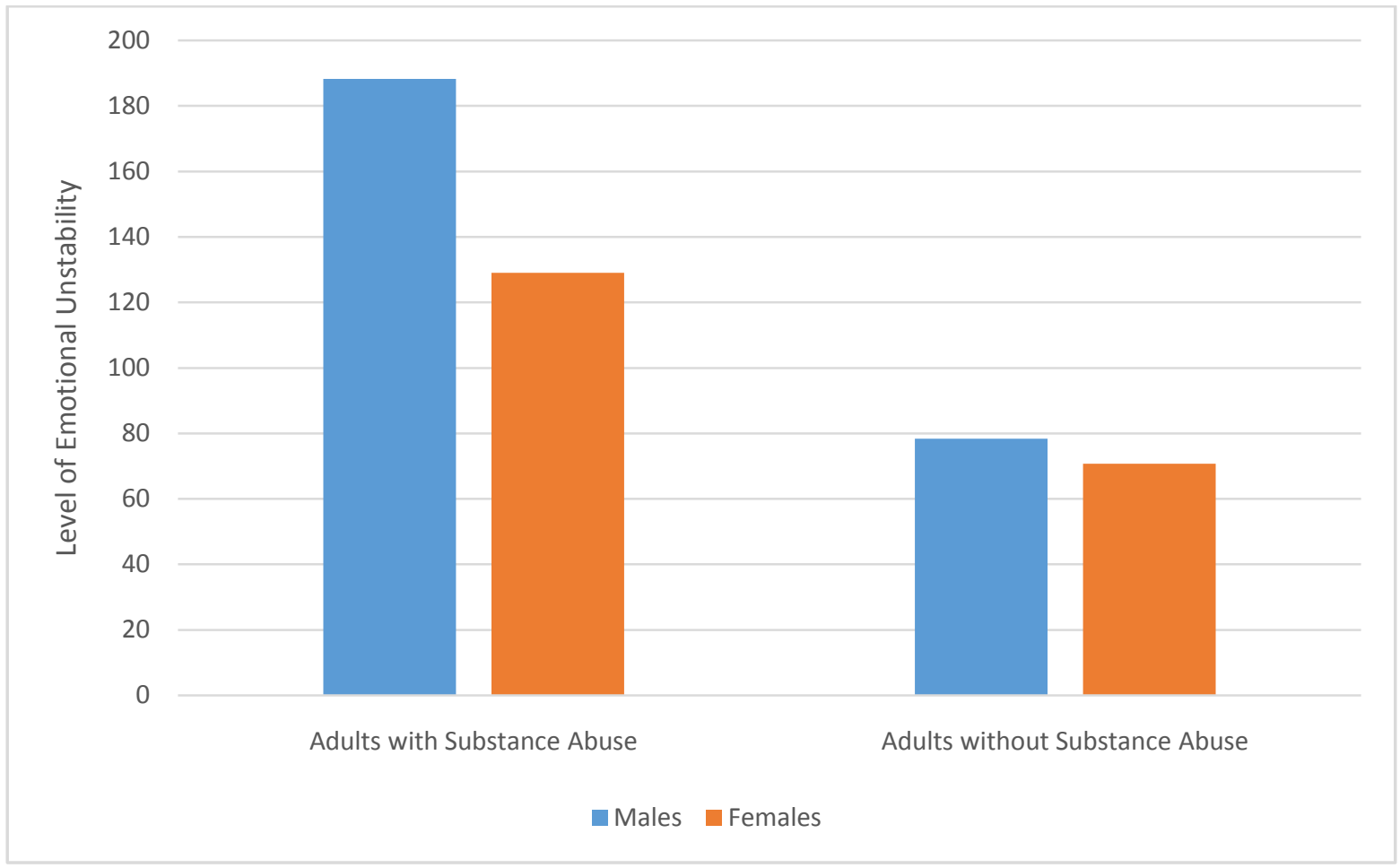


Attachment Style, Emotional Maturity and Self-Esteem among Adults With and Without Substance Abuse

Graph 6 - Showing the mean value of self-esteem among adults with substance abuse and without substance abuse.

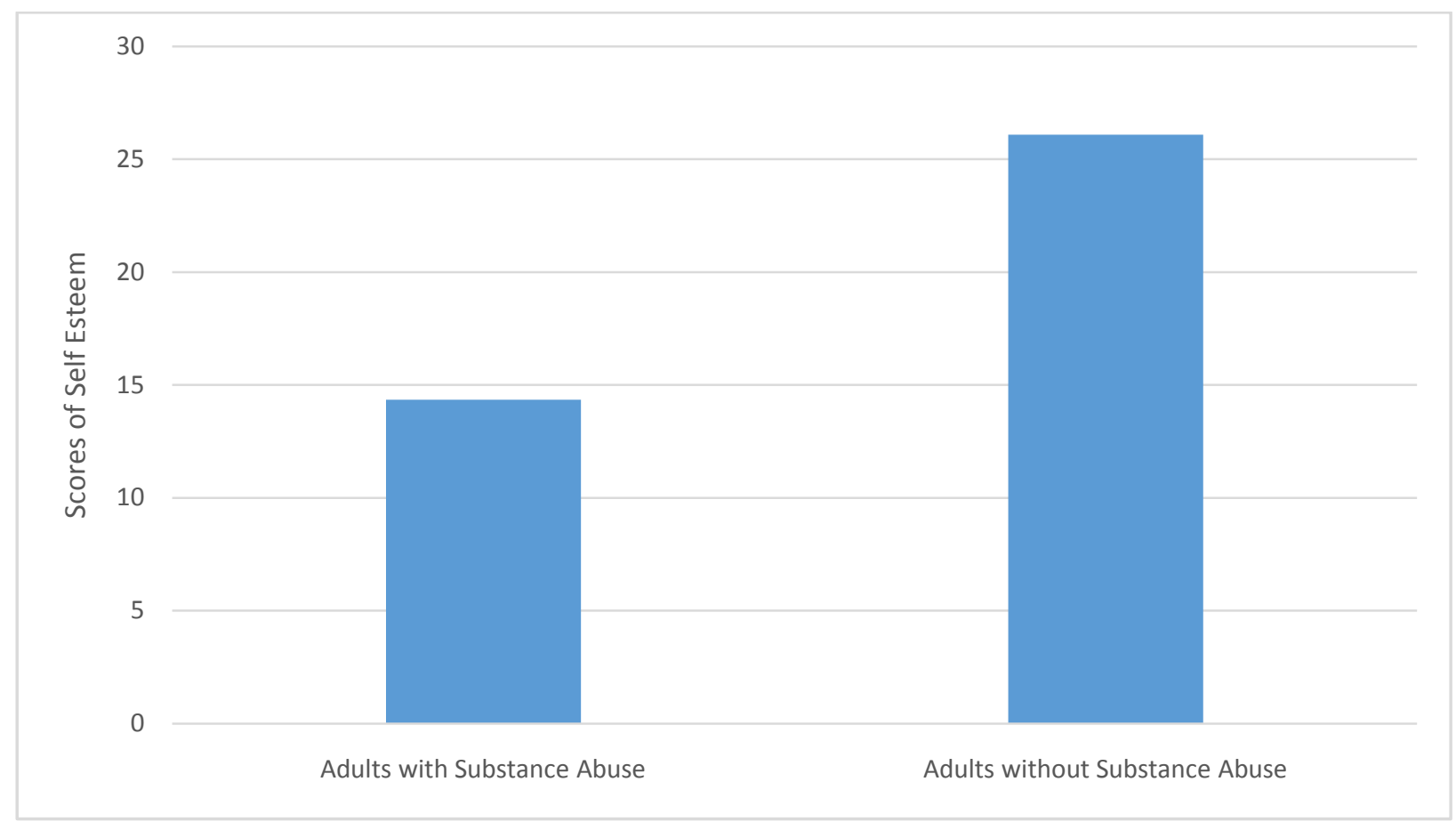

Graph 7 - Showing the mean value of self-esteem between adult males and females with substance abuse and without substance abuse.

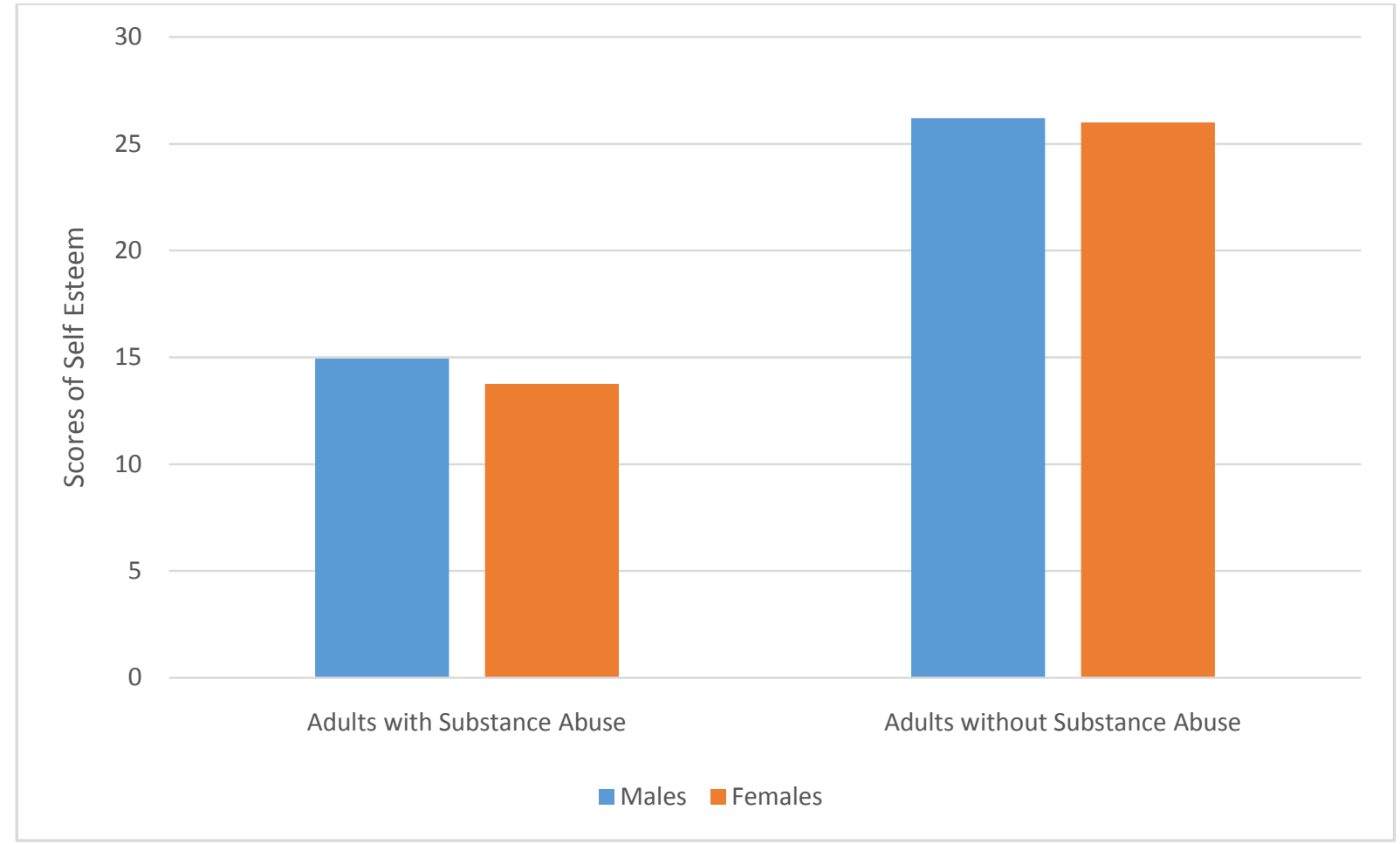




\section{Attachment Style, Emotional Maturity and Self-Esteem among Adults With and Without Substance Abuse}

\section{DISCUSSION}

Following are the results which were found out after in-depth analysis of the scores:

There was a significant difference in secure attachment style of substance abusers and nonabusers. The adults who do not abuse substances tend to have a secure attachment style i.e. they have a positive view of the self, others and relationships. Also there was a significant difference in insecure attachment style of adults who abuse substances and who do not abuse substances. The adults with substance abuse tend to have an insecure style of attachment. The reasons of the result could be that substance abusers avoid or ignore the caregiver - showing little emotion when the caregiver leaves or returns. A significant difference could not be established between male and female adults who abuse substances in secure attachment style. There was a significant difference between both the genders with substance abuse in insecure attachment style, with male adults having more insecure attachment pattern than female adults. Also it was found that there was significant difference in secure attachment pattern of male and female adults without substance abuse whereas there was no significant difference between both the genders in insecure attachment pattern among adults without substance abuse. Various researchers have proven that attachment style affects substance abuse, emotional distress and interpersonal problems in adults. Thorberg and Lyvers (2006) stated that clients who were undertaking treatment for alcoholism, heroin addiction, or cannabis abuse reported higher levels of insecure attachment and fear of intimacy.

There was a significant difference between the emotional maturity of substance abusers and nonabusers. The adults who abuse substances tend to be extremely unstable on the level of emotional maturity i.e. they find it hard to deal with the normal challenges of life, feel unable to cope and suffer from stress. Whereas, adults who do not abuse substances tend to be extremely stable on the level of emotional maturity i.e. they able to see each situation as unique and can adapt to a style accordingly, take responsibility of their own life, are resilient and seek for personal growth. Norton (2008) said that during youth, substance abuse fixes the brain at the same level of maturity as it was when drug use began. Hatch (2013) said that addicts tend to be more emotionally immature than non-addicts. Rose (2014) indicated that substance abuse can stunt emotional growth. There was significant gender differences among the adults of both substance abuse and without substance abuse. Male adults who abuse substances are more unstable emotionally than females who abuse substances also female adults without substance abuse are more stable emotionally than males. Rajkumar, A. (2012) indicated that there is a significant gender difference in emotional maturity as the female employees were better than the male employees in the area of emotional maturity skills.

There was a significant difference between the self-esteem of substance abusers and non-abusers. The adults who do not abuse substances tend to have higher self-esteem than adults who abuse substances. Low self-esteem results in social withdrawal, anxiety and emotional turmoil. They lack self-confidence and social skills, may suffer from depression or bouts of sadness and have 


\section{Attachment Style, Emotional Maturity and Self-Esteem among Adults With and Without Substance Abuse}

less social conformity. Whereas People who have high self-esteem have confidence in their own abilities, know what they want, have effective communication skills and drive to succeed. Various researches support these findings. Alavi, (2011) reported that self-esteem had a significant role in the individual's tendency to addiction. Kounenou (2010) stated that high selfesteem is a predictor of anticipation of drugs and narcotics. Ogborne and Smart (1994) also reported that individuals undergoing treatment for substance abuse had low self-esteem. There was no significant gender differences among the adults with substance abuse and without substance abuse. Whereas, male adults who abuse substances and also who do not abuse substances have higher self-esteem than females who abuse substances. This is verified by the study done by Kling et al. (1999). They examined gender differences in global self-esteem. It indicated higher male self-esteem than females but the difference was small.

\section{CONCLUSION}

The current research aimed to study Attachment Style, Emotional Maturity and Self Esteem among Adults With and Without Substance Abuse. The sample comprised of 80 participants, i.e. 40 substance abusers and 40 substance non abusers in which 20 males and 20 females from both the group were taken as sample. The age range of the participants was $18-30$ years. Tools used in the study were Relationship Scale Questionnaire, Emotional Maturity Scale and Rosenberg Self-Esteem Scale to assess the variables: attachment style, emotional maturity and self-esteem. The findings of the study were that there was a significant difference in both secure and insecure attachment style, self-esteem and emotional maturity of the adults with substance abuse and without substance abuse. It was also found that there was no significant difference between male and female adults with substance abuse in secure attachment style and self-esteem. But there was a significant difference in insecure attachment style and emotional maturity among male and female adults with substance abuse. Among the male and female adults without substance abuse, it was found that there was a significant difference in secure attachment pattern and emotional maturity. But there was no significant difference in insecure attachment pattern and self-esteem among the male and female adults without substance abuse. Some limitations of the study included that the tools used for attachment style and self-esteem were not validated for Indian population. Also other variables, such as parental substance abuse, participant's style of living, duration of treatment taken by them and their family structure, need to be taken into consideration. Further suggestions also include that substance abuse could be studied in relation with other psychological variables and correlation between substance abuse and the psychological measure could be found. The various dimensions of variables could also be studied by comparing them between individuals who abuse substance and who do not abuse substances to make the study more in-depth. Studies could be done by researchers to find out the effect of different types of substances people abuse in relation with various psychological measures. The social implication of the study includes providing an insight about enhancing selfdevelopment in the context of peers, family, close relationships and global settings. Thus, preventing and treating substance abuse in early years of life as the present study has proven that 


\section{Attachment Style, Emotional Maturity and Self-Esteem among Adults With and Without Substance Abuse}

there is significant difference in the attachment styles, level of emotional maturity and self esteem of adults with substance abuse and without substance abuse.

\section{REFERENCES}

Alavi, H. R. (2011). The Role of Self-esteem in Tendency towards Drugs, Theft and Prostitution. Addiction \& health, 3(3-4), 119.

Hatch, L. (2013). Gaining Emotional Maturity is Key to Addiction Recovery. Retrieved January 5, 2015, from http://blogs.psychcentral.com/sex-addiction/2013/06/gaining-emotionalmaturity-is-key-to-addiction-recovery/

Kahn, A. P., \& Fawcett, J. (1993). The encyclopedia of mental health. New York: Facts on File.

Karairmak, Ö.,\& Duran, N. O. (2008). Gender differences in attachment styles regarding conflict handling behaviors among Turkish late adolescents. International Journal for the Advancement of Counselling, 30(4), 220-234.

Kassel, J. D., Wardle, M., \& Roberts, J. E. (2007). Adult attachment security and college student substance use. Addictive behaviors, 32(6), 1164-1176.

McNally, A. M., Palfai, T. P., Levine, R. V., \& Moore, B. M. (2003). Attachment dimensions and drinking-related problems among young adults: The mediational role of coping motives. Addictive behaviors, 28(6), 1115-1127.

Rajkumar, A. (2012). A Study on Emotional Maturity and Gender Differences in Government Employees.

Richard J. Rose, Torsten Winter, Richard J. Viken, Jaakko Kaprio. Adolescent Alcohol Abuse and Adverse Adult Outcomes: Evaluating Confounds with Drinking-Discordant Twins. Alcoholism: Clinical and Experimental Research, 2014; DOI: 10.1111/acer.12491

Shrier, L. A., Harris, S. K., Sternberg, M., \& Beardslee, W. R. (2001). Associations of depression, self-esteem, and substance use with sexual risk among adolescents. Preventive medicine, 33(3), 179-189.

Winograd, R. (2012, July 2). Emotional maturity and substance abuse. Retrieved January 3, 2015, from https://www.benchmarkcenter.com/emotional-maturity-and-substance-abuse/ 